Available online: https://journals.researchsynergypress.com/index.php/ijebce/ International Journal of Entrepreneurship, Business and Creative Economy (IJEBCE) ISSN 2775-3085 (Online) | 2775-3107 (Print)

Volume 2 Number 1 (2022): 37-47

\title{
Online Purchase Intention: A Study Among Gen X in Malaysia
}

\author{
Anushia Chelvarayan', Lim Fu Hao1, Yeo Sook Fern'1, Hazlaili Hashim1 \\ 1Faculty of Business, Multimedia University Melaka, Malaysia
}

\begin{abstract}
In recent years, changes in the commercial sector, combined with the increasing popularity of the Internet, have made Malaysian businesses increasingly conscious of the relevance of E-business in establishing a competitive edge in the worldwide market. As a result, knowing the elements that drive online purchase intention could help marketers create more effective marketing techniques for specific categories. Trust, product and service quality, customer satisfaction, and delivery speed are the four characteristics that influence online purchase intention in this study. According to 203 Generation X respondents, three characteristics had a significant impact on online purchase intention. The only exception was the product and service quality. The data and information acquired in this study will aid researchers, online platform developers, financial institutions, marketers, and the government because we will be able to examine and understand the elements that encourage Gen $\mathrm{X}$ in Malaysia to purchase online.
\end{abstract}

Keywords: Generation X; Purchase intention; Online shopping

This is an open access article under the CC-BY-NC license.

\section{INTRODUCTION}

As a result of globalisation, the use of information technology (IT) has exploded, with the Internet becoming ubiquitous. The Internet, according to Damanpour \& Damanpour (2001), has changed not only how people live but also how businesses conduct business, interact and exchange information, and sell and acquire goods and services. According to Sulaiman et al., the majority of businesses use the Internet to save marketing costs and improve competitiveness (2008). This, they believe, is in line with increasing customer happiness and profit margins. E-commerce (electronic commerce) is undoubtedly here to stay. Electronic commerce is defined as a business that operates primarily through digital communication and information technology. The sale and purchase of goods and services using computer networks, especially the Internet, is known as e-commerce (Wen, Chen, and Hwang 2001). Changes in the commercial sector, combined with the growing popularity of the Internet, have made Malaysian enterprises more aware of the importance of Ebusiness in gaining a competitive advantage in the global market in recent years. As a result, a better understanding of the factors that influence online purchasing intention would aid in the development of more targeted marketing strategies. People acquire items for a variety of reasons that are usually hidden beneath the surface of their age and generational cohorts (Kaur and Anand, 2018; Tan and Leby Lau, 2016). Cohorts are groups of people who were born around the same time and have shared their lives. Because generational cohort marketing is based on age, it has shown to be effective in identifying people in each cohort who share common beliefs (Parment, 2013; Schewe et al., 2013). Generation X refers to the generation of Americans born between the mid-1960s and the early 1980s. Gen Xers make up around 65 million people, which includes both baby boomers 
International Journal of Entrepreneurship, Business and Creative Economy (IJEBCE), Vol. 2 (1), 37-47

Online Purchase Intention: A Study Among Gen X in Malaysia

Anushia Chelvarayan, Lim Fu Hao, Yeo Sook Fern, Hazlaili Hashim

and millennials. This generation is nearing the peak of their working lives and maybe entering their prime earning years. They are currently between the ages of 41 and 56, having been born between 1965 and 1979/80.

Furthermore, online shopping is a sort of electronic commerce that allows customers to legally purchase goods or services from a seller via the Internet using a web browser. E-web-store, Internet shop, web-shop, web-store, online store, online retail facade, and virtual store are some of the alternative names. Purchasing from an online retailer's adaptable enhanced online website or application is referred to as mobile commerce. The method is known as business-to-consumer (B2C) internet shopping, and it replicates the actual experience of purchasing things or services at a brick-and-mortar retailer or strip mall. As a result, the method is known as business-to-business (B2B) for the scenario in which a company buys from another company. Aside from that, the largest of these web-based commerce businesses are Alibaba, Amazon.com, and eBay. With the growth of internet buying, a plethora of new market impressions integrates opportunities for retailers that can appropriately consider seaward market requests, and administrative requirements have opened up for them.

Although Generation Y, with its pleasure-seeking, extravagance, and great connectivity, is considered to be a more attractive target population for businesses, it is important to direct marketing efforts toward Generation X, which according to the literature, buys more due to higher disposable income, and more free time (Peralta, 2015; Jones and Fox, 2009). As a result, the purpose of this research is to examine Gen X's particular traits in terms of affecting online purchasing intent in Malaysia. Based on Gen X's specific ideas and traits, the conclusions of this study give marketers and policymakers advice on how to better appeal to them.

\section{LITERATURE REVIEW}

Internet retailers, unlike traditional physical stores, consolidate the entire sales process into a single platform (Mummalaneni and Meng, 2009). Because internet shopping is free of spatial and temporal constraints, consumers benefit from increased convenience. They can't touch, taste, or feel the real items they're buying online, though. According to Younus (2015), purchase intention is a customer's desire to buy a product or service. A consumer's decision to buy a product is influenced by a variety of circumstances, and the final decision is based on the consumer's willingness to use a wide range of external variables (Keller, 2001). In the past, the intention was defined as the driving force behind a customer's decision to purchase goods or services (Hawkins \& Mothersbaugh, 2010). Customers' behaviour and purchase intentions are intricately intertwined (Kim \& Pysarchik, 2000).

Trust is recognised as a critical component in buyer-seller interactions and online purchase intention in electronic commerce (Jarvenpaa et al., 1999; Zhou et al., 2007; Naveed and Eddaoudi 2009; Yulihasri et al.2011; Swidi et al., 2012). In the context of e-commerce, trust refers to the online consumer's expectations of the characteristics of the online supplier (McKnight et al., 2002). According to Kraeuter (2002), the most significant long-term barrier to customers understanding the potential of e-commerce in an online context is a lack of trust. People place a lot of trust in the product, the salesperson, and/or the company when making major purchases (Kim et al., 2008). According to the study from Miss Valerie Malecha (Malecha, 2018), the way to prevent scammers from making online purchases is at first, as a customer should check the website and the seller 
International Journal of Entrepreneurship, Business and Creative Economy (IJEBCE), Vol. 2 (1), 37-47

Online Purchase Intention: A Study Among Gen X in Malaysia

Anushia Chelvarayan, Lim Fu Hao, Yeo Sook Fern, Hazlaili Hashim

information before making a decision to purchase with. For example, check the seller's business email address and phone number on the "Contact" page on their site. Besides that, a customer also can take a look at the previous customer review so that it could avoid scams and also the quality of the products and services (Malecha, 2018). Another way to avoid scammers is to manage and protect online passwords. Due to having a strong and unique password, the hackers will not that easily log in to your account (Duffy, 2015). According to (Schaupp, 2005), security opportunities are defined as a situation or circumstance that can organize properties or data to the point of demolition, waste, misuse, theft, and information alteration through financial hardship. According to Chen et al. (2026) remarked that security hazards will affect the online purchase intention among generation X. Besides that, a trustable and secure online page will affect generation X's willingness to purchase, and online stores are influenced by customers' trust in giving individual data and security for installment through charge card exchanges. Therefore, in this case, an online business should always pay attention to their website's security so that the consumer will not be deceived or any scams happen. Therefore, generation X can rest assured while using online shopping to purchase their wants and needs from online shopping.

To conclude, the relationship between security and online purchases intention among generation $\mathrm{X}$, an online shop that is secure, will affect the increment of generation $\mathrm{X}$ to purchase in online shopping. Therefore, having an SSL Certificate from Veridign can make the most trusted mark online. Those consumers who enter the website can put 100 percent to use it. According to (Sahney, 2013), the study also stated that reliability is one of the assessment variables for an online shop's perceived reputation and is assessed by the integrity and accuracy of online trust-related website services. In addition, the risk of privacy is also possible, which is associated with the issue of loss of privacy due to customers needing to provide personal information while shopping online (Mansori, 2012). The ability of consumers to monitor, regulate and selectively reveal their personal information can be described as privacy (al, 2006). Hence, Chen (al C. e., 2016) suggests to remove customer privacy issues and improve the purpose of online shopping, privacy policies are required.

Product quality is a competitive market for companies that influences purchasing decisions and profitability, regardless of public perception (Staff, 2018). As a result, any company must place a premium on high-quality goods and services. Because providing clients with low-quality products and services would generate a poor reputation and stifle the company's growth (Avenir, 2018). Product quality should also be a continual improvement process that results in the execution of products and services as well as the fulfilment of client requests and wants. Moreover, the product quality should be a non-stop procedure of progress that the persistent changes increment products \& services execution and fulfillment of customer's needs and want. On the other hand, the quality could be satisfying customer wants and needs. Achieving customer satisfaction involves using a list of observable attributes. The product's quality is calculated on the basis of whether it meets the needs of the customer in terms of consumption and use. Clearly, it's better for a business to focus on using a mixture of these two concepts. Through doing so, the business can ensure that the products and services can fulfil the specifications and simultaneously satisfy the needs of consumers (Writer, 2020). Moreover, the impact of quality orientation on online purchase intention in the current literature is well known. Therefore, the quality of the products and services will be a serious impact on the online purchase intention among generation X (eSalesTrack, 2010). For example, a customer purchasing his/her product online and the quality of the product is not 
International Journal of Entrepreneurship, Business and Creative Economy (IJEBCE), Vol. 2 (1), 37-47

Online Purchase Intention: A Study Among Gen X in Malaysia

Anushia Chelvarayan, Lim Fu Hao, Yeo Sook Fern, Hazlaili Hashim

satisfactory. Thus, the customer will choose a physical store compared with online shopping. Due to the increased quality of the products and services, there have certain ways to improve it and overcome the problems faced by generation X. To Establish a long-term quality improvement plan, split it into small steps, and then adjust to meet each step's objectives. Besides that, offer quality and supreme priority in all plans and procedures. Note, changing quality over time, cost or labour may provide temporary advantages but kill the future permanently. Moreover, keep comparing the product feature with competitors so that can easily find out the difference and surpass them. To conclude, the good quality of products and services could bring advantages to compare with another competitor in the market. Hence, a business should make more effort in improving their products and services quality so that could attract new customers.

One of the most important factors in predicting consumer purchase intention is customer happiness. Customer satisfaction is a measure of how pleased customers are with a company's products and services (Fontenot, 2005). Because a customer might stop being a customer at any time and lose their commitment to a company's product or service in an instant, customer happiness is critical. Contentment is examined in terms of results in this study by comparing prior expectations and perceived output for each element in order to determine the respondents' attitudes toward those factors, satisfaction, and gratification (Jiradilok, 2014). Customers who return prefer to buy more from a business over time. Your running expenses for serving them drop as they do. What's more, return customers refer others to your agency. And to continue doing business with you, they will always pay a premium instead of going to a rival with whom they are neither acquainted nor relaxed (Reichheld, 2020). Past experience is a reliable information cue to inform future decisions and helps to form stable, long-term relationships. People give more weight to past experience in such certain and stable situations. Online shopping enjoyment is the perceived gratification derived from a website experience, the degree to which customers consider the process of using a website to be enjoyable (Mutambala, 2015). According to (Ha, 2011), the customer will have a feeling of enjoyment during visiting a website page while having their online purchasing. Therefore, it could increase the online purchases intention among customers by contributing to an enjoyable shopping experience. By supporting Heijden (2004), that stated enjoyment is an important construct that will influence the purchase intention of customers to purchase online, and the online businesses will gain benefit from making their websites more enjoyable. On the other hand, the effective way to improve customer satisfaction is to collect customer feedback, for example, a survey form which is more effective and efficient to know the problems faced by the customer (Kierczak, 2020). Therefore, the businesses could understand what the obstacles faced by customers and places to improve are. Thus, the customer will be willing to repurchase their needs and wants in the online business (Copley, 2017). To conclude, customer satisfaction plays an important role. It is not only the leading indicator for assessing customer satisfaction, identifying dissatisfied customers, minimizing turnover, and increasing revenue (Patel, n.d.). Thus, it is also a crucial point of differentiation that allows you in competitive market environments to gain attention from new customers' approaches.

Last but not least, there's the issue of delivery time. Delivery time refers to the time it takes for products purchased to arrive at the location where they are required (Larus, 2013). According to (Staff, 2016), 87 percent of online buyers consider delivery speed as a crucial influence in their decision to shop with an e-commerce company again. According to Parry (2016), delivery speed is 
International Journal of Entrepreneurship, Business and Creative Economy (IJEBCE), Vol. 2 (1), 37-47

Online Purchase Intention: A Study Among Gen X in Malaysia

Anushia Chelvarayan, Lim Fu Hao, Yeo Sook Fern, Hazlaili Hashim

the single factor that influences consumer loyalty and brand perception. As a result, a precise delivery time can help a company's earnings as well as its brand image. According to (PadrónRobaina, 2014), the businesses are immediately complying with what it has promised and keep the customer well updated. E-commerce is growing more than 15 percent last year alone, but the delivery infrastructure is struggling to get clients on their terms with almost $\$ 395$ billion in orders (Staff L. D., 2017). Besides that, the delivery delay has some of the reasons that occur (Logistiko, 2020). The main reason is that the weather is unknown, such as heavy rain and foggy weather. In mother nature, this situation is uncontrollable. Therefore it may seriously affect the delivery time accuracy. Another reason is the documentation mistakes (Logistiko, 2020). For example, misspelled addresses, incorrectly completed order forms, and uncompleted information. These issues may cause failure to deliver the products or services in time to the customer. Moreover, the methods to prevent delivery delay are monitored in the production to improve lead time. For most importers who just want a snapshot of order quality once or twice before shipment, inspections during manufacturing and pre-shipment are suitable. But you might need broader insight, especially if you've been experiencing prolonged production delays (Burkhart, 2019). Besides that, Acquire Automated Logistic Software could help solve the delivery time exceed. Thus, by using automation could improve customer service because this software may allow the customer to know the freight costs and the time their products or services arrive (Katie-Zillmer, 2019).

\section{RESEARCH METHOD}

The most important component of the research process is the research framework, which is the structure that supports the research hypotheses. The link between the dependent and independent variables is depicted in Figure 1 by the dependent and independent variables. The research design was built around the connections between purchase intention among Gen $\mathrm{X}$ and trust, product service and quality, customer satisfaction, and the delivery time as independent variables. The independent variables are utilised as intermediate variables to assess the factors influencing Gen $\mathrm{X}$ 's buying intentions in Malaysia.

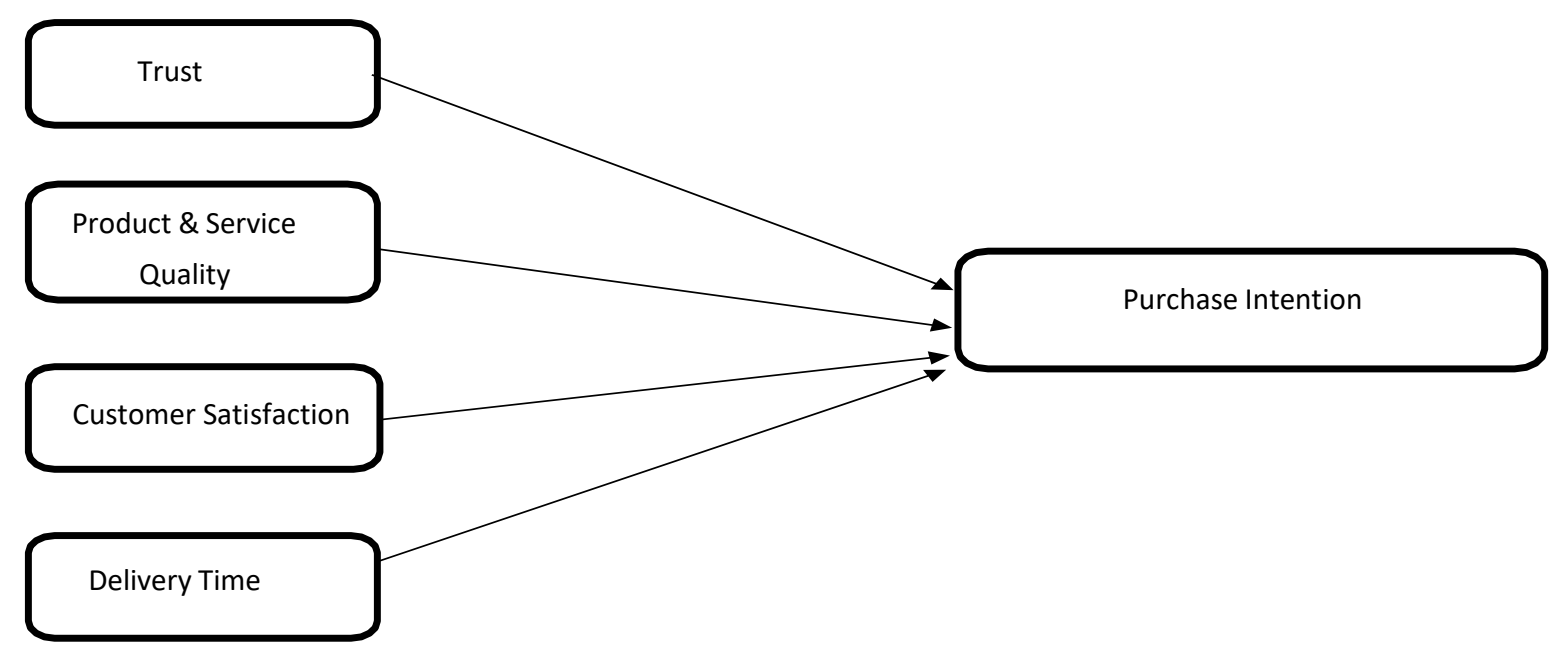

Figure 1: Research Framework (Developed for this research) 
International Journal of Entrepreneurship, Business and Creative Economy (IJEBCE), Vol. 2 (1), 37-47

Online Purchase Intention: A Study Among Gen X in Malaysia

Anushia Chelvarayan, Lim Fu Hao, Yeo Sook Fern, Hazlaili Hashim

Population, according to the study, is a determinable total interest base. A group of Gen Xers (those aged 41 to 56) from various parts of Malaysia took part in this study. The survey had a total of 203 responses (based on $\mathrm{G}^{*}$, the minimum sample size is 128). The researchers chose samples based on their subjective judgement in this study, which used non-probability sampling. Convenience sampling was used in this investigation. Because of its speed, cost-effectiveness, and sample availability, this sampling method was chosen. All of the data is collected through questionnaires. Respondents will fill out the questionnaire online, and their responses will be collected electronically. Questionnaires were delivered face to face and in electronic form.

The demographic data, the ideas included in this study, and their interactions are all analysed using the Statistical Package for the Social Sciences (SPSS). Because SPSS can handle a huge quantity of data, it was able to execute all of the analyses in this study. Because SPSS is compatible with a range of other data analysis software programmes, it was used in this investigation.

\section{FINDINGS AND DISCUSSION}

To provide a clear understanding, the findings are reported in the tables below. The theories that were created were also tested and summarised as follows:

Table 1: Demographic Information

\begin{tabular}{|l|l|l|l|}
\hline Variables & & Frequency & Percentage (\%) \\
\hline \multirow{4}{*}{ Gender } & Male & 83 & 40.9 \\
& Female & 120 & 59.1 \\
\hline \multirow{5}{*}{ Race } & $40-43$ & 76 & 37.4 \\
& $44-47$ & 47 & 23.2 \\
& $48-51$ & 73 & 36.0 \\
& $52-55$ & 7 & 3.4 \\
\hline \multirow{5}{*}{ Highest Level of Education } & Malay & 34 & 16.7 \\
& Chinese & 142 & 70 \\
& Indian & 26 & 12.8 \\
& Others & 1 & 5 \\
\hline Income Level & SPM & 22 & 10.8 \\
& Foundation & 19 & 9.4 \\
& Diploma & 63 & 31.0 \\
& Degree & 97 & 47.8 \\
& Postgraduate & 2 & 1.0 \\
\hline Monthly Online Purchases & Below RM1000 & 30 & 14.8 \\
& RM1501-RM3000 & 58 & 28.6 \\
& RM3001-RM4500 & 84 & 41.4 \\
& RM4501 and above & 31 & 15.3 \\
\hline & 1-3 times & 75 & 36.9 \\
& 4-7 times & 79 & 38.9 \\
& 8-10 times & 40 & 19.7 \\
& More than 10 times & 9 & 4.4 \\
\hline
\end{tabular}

Table 1 summarises the demographic information collected for this research, with a total of 203 respondents who are in the Gen X cohort from all over Malaysia. 
International Journal of Entrepreneurship, Business and Creative Economy (IJEBCE), Vol. 2 (1), 37-47

Online Purchase Intention: A Study Among Gen X in Malaysia

Anushia Chelvarayan, Lim Fu Hao, Yeo Sook Fern, Hazlaili Hashim

Table 2: Reliability Analysis

\begin{tabular}{|l|l|l|}
\hline Dependent Variables & Cronbach's Alpha & Number of Item \\
\hline Purchase Intention & 0.820 & 3 \\
\hline Independent Variables & Cronbach's Alpha & Number of Item \\
\hline Trust & 0.870 & 5 \\
\hline Product \& Servive Quality & 0.874 & 4 \\
\hline Customer Satisfaction & 0.871 & 4 \\
\hline Delivery Time & 0.802 & 3 \\
\hline
\end{tabular}

Table 2 shows the Cronbach's Alpha for each variable. All of the variables in this study had Cronbach's Alpha values over 0.7 , indicating that they were all acceptable. The independent factors with the greatest Cronbach's Alpha are product and service quality (0.874), customer satisfaction (0.871), trust (0.870), and delivery time (0.802). At the same time, Cronbach's Alpha for the dependent variable of purchase intention was 0.820 .

Table 3: Coefficients

\begin{tabular}{|c|c|c|c|c|c|}
\hline \multirow[b]{2}{*}{ Model } & \multicolumn{2}{|c|}{$\begin{array}{l}\text { Unstandardized } \\
\text { Coefficients }\end{array}$} & \multirow{2}{*}{$\begin{array}{c}\begin{array}{c}\text { Standardized } \\
\text { Coefficients }\end{array} \\
\text { Beta }\end{array}$} & \multirow[b]{2}{*}{$\mathbf{t}$} & \multirow[b]{2}{*}{ Sig. } \\
\hline & B & Std. Error & & & \\
\hline (Constant) & .110 & .162 & & .678 & .499 \\
\hline Trust & .137 & .063 & .133 & 2.177 & .031 \\
\hline $\begin{array}{l}\text { Product \& Servive } \\
\text { Quality } \\
\end{array}$ & .034 & .063 & .034 & .545 & .586 \\
\hline $\begin{array}{l}\text { Customer } \\
\text { Satisfaction }\end{array}$ & .244 & .066 & .238 & 3.695 & .000 \\
\hline Delivery Time & .629 & .063 & .601 & 9.977 & .000 \\
\hline
\end{tabular}

Table 3 shows the result of coefficients analysed by SPSS. Table 3 demonstrates the relationship between dependent and independent variables through multiple linear regression analysis. The hypothesis is supported if the p-value (significance level) does not exceed 0.05 . Thus, Table 3 shows that three of independent variables of the study trust, customer satisfaction, and delivery time has a significant positive relationship towards the online purchase intention among Gen X in Malaysia, where the variables of $\mathrm{p}$ - value of trust, customer satisfaction, and delivery time is $0.031,0.000$ and 0.000 respectively. However, product service and quality do not have a significant relationship with the online purchase intention among Gen X in Malaysia. This is due to the p- value being more than 0.05 as the product \& service p- value is 0.586 . This, however, supports our understanding as to when customers make an online purchase, they have verified the product service and quality and are prepared to receive the service and product as described in the purchasing platform. Unlike physical purchases, where customers are able to gauge the quality before purchase, online customers have to rely on the description and reviews stated online. Hence, this supports the above results. 
International Journal of Entrepreneurship, Business and Creative Economy (IJEBCE), Vol. 2 (1), 37-47

Online Purchase Intention: A Study Among Gen X in Malaysia

Anushia Chelvarayan, Lim Fu Hao, Yeo Sook Fern, Hazlaili Hashim

Table 4: Hypothesis Testing

\begin{tabular}{|l|l|l|l|}
\hline No. & Hypothesis & p-value & Results \\
\hline H1 & $\begin{array}{l}\text { There is a significant relationship } \\
\text { between trust and online purchases } \\
\text { intention among generation X in Malaysia. }\end{array}$ & 0.031 & Supported \\
\hline H2 & $\begin{array}{l}\text { There is a significant relationship } \\
\text { between product \& services quality and } \\
\text { online purchases intention among } \\
\text { generation X in Malaysia. }\end{array}$ & 0.586 & Rejected \\
\hline H3 & $\begin{array}{l}\text { There is a significant relationship } \\
\text { between customer satisfaction and } \\
\text { online purchases intention among } \\
\text { generation X } \\
\text { in Malaysia. }\end{array}$ & 0.000 & Supported \\
\hline H4 & $\begin{array}{l}\text { There is a significant relationship } \\
\text { between delivery time and online } \\
\text { purchases intention among generation X } \\
\text { in Malaysia }\end{array}$ & 0.000 & Supported \\
\hline
\end{tabular}

Table 4 displays the results of the SPSS analysis of coefficients. The hypothesis is supported if the significant value (also known as the p-value) does not exceed 0.05. Three independent variables are significant among four independent variables, according to the table above. In this study, trust (0.031), customer satisfaction $(0.000)$, and delivery time $(0.000)$ are all significant. Product and service quality (0.065) is not significant in the study because it exceeds 0.05 .

\section{CONCLUSION \& FURTHER RESEARCH}

The technologically savvy generation $X$ presents a significant opportunity for internet businesses, and the conclusions of this study can benefit both academics and marketers. The study's main purpose was to learn more about the factors that influenced Generation X's online shopping intentions in Malaysia. Four elements were found as important in this study: trust, product and service quality, customer satisfaction, and delivery. With the exception of the third component, product and service quality, all of the other variables were demonstrated to have a significant impact on online purchase intention.

To boost e-commerce, even more, the government should try to educate the public about the benefits of shopping online in Malaysia. For example, the government may collaborate with well-known Malaysian online shopping platforms like Shopee, Lazada, and Grab Malaysia to boost e-commerce awareness, especially during this epidemic period. Malaysia's economy would surely benefit from online buying, as would retailers that are unable to perform physical transactions.

These findings could aid in the development of a more comprehensive model to aid researchers in better understanding online purchasing intent. The conclusions of this study, which looked at Malaysia's Generation X consumer behaviour, would help marketers better understand Malaysian buying intents and design more effective online marketing strategies. They will be able to build a good platform for these Gen Xers to ensure that the needs of this group are fulfilled, especially the need of trusty, satisfied sellers that fulfils the urgency of prompt delivery. When conducting research, however, there are many limits to be mindful of. The study's sample size was tiny, to begin with, with only 203 individuals. As a result, the figures may not accurately reflect internet shopping among Malaysia's Generation X.

Second, the information cannot be obtained quickly enough. This is the situation because the majority of respondents are unwilling or unable to complete the survey. As a result, obtaining 
International Journal of Entrepreneurship, Business and Creative Economy (IJEBCE), Vol. 2 (1), 37-47

Online Purchase Intention: A Study Among Gen X in Malaysia

Anushia Chelvarayan, Lim Fu Hao, Yeo Sook Fern, Hazlaili Hashim

data will be more challenging for researchers. More studies should be done to gather a larger sample size of respondents from various parts of Malaysia. Researchers may be able to draw more definite conclusions regarding the association between the elements if they have a larger sample size. To improve the accuracy of the data collected, the surveys should be distributed to multiple locations.

Next, the risk of bias may have impaired the accuracy of the findings. As a result, it is suggested that more variables, moderators, and mediators be added in future studies in order to construct a more comprehensive study model. Furthermore, due to the subjective nature of customer behaviour, a mix of qualitative and quantitative research is required. To summarise, longitudinal research over a longer length of time and with larger sample size is recommended for more credible results.

\section{REFERENCES}

Avenir, R. (2018). What Are the Four Ways in Which Quality Can Affect a Company? azcentral.

Burkhart, M. (2019). 3 Ways to Prevent Shipment Delays with Your Overseas Suppliers. Retrieved from Freightos: https://www.freightos.com/freight-resources/prevent-delays-withoverseas-suppliers/ Copley, L. (2017). 6 reasons why customer satisfaction is important. Retrieved from The Calltakers: https://www.allaboutcalls.co.uk/the-call-takers-blog/6reasons-why-customer-satisfaction-is important Damanpour, F. \& J.A. Damanpour, (2001). 'Ebusiness e-commerce evolution: perspective and strategy', Managerial Finance, 27(7): 16-33.

Duffy, J. (2015). 10 Simple Things You Can Do to Be More Secure Online. Retrieved from PCMag Asia: https://sea.pcmag.com/software/2430/10-simple-things-you-can-do-to-be-moresecure-online

eSalesTrack. (2010). IMPROVING QUALITY OF PRODUCTS AND SERVICES. Retrieved from eSalesTrack Blog: http://www.esalestrack.com/blog/2008/06/improving-quality-ofproducts-and.html Fontenot. (2005). Take action on customer satisfaction . Retrieved from https://asq.org/quality-progress/articles/take-action-on-customersatisfaction?id=39b4d69d02dc4cfb895a075ceee63a2b

Ha, I. \&. (2011). Consumers' online purchase . Linnaeus University , 15-18.

Hawkins, D., \& Mothersbaugh, D. (2010). Consumer behaviour: Building marketing strategy (11th ed.). New York, NY: McGraw Hill.

Heijden, V. D. (2004). Consumers' online purchase intention in cosmetic products. Linnaeus University, 16-17.

Jarvenpaa, S.L., N. Tractinsky, L. Saarinen and M. Vitale, (1999). Consumer Trust in an Internet Store: A Cross-Cultural Validation, Journal of Computer-Mediated Communications, 5(2)

Jiradilok, T. (2014). The Impact of Customer Satisfaction on Online Purchasing. Journal of Economics, Business and Management, 5.

Jones, S., and Fox, S. (2009). Generations Online in 2009. Pew Research Center. http://www.pewinternet.org/2009/01/28/generations-online-in-2009/\#

Kaur, H. and Anand, S. (2018), "Segmenting generation Y using the big five personality traits: understanding differences in fashion consciousness, status consumption and materialism", Young Consumers, Vol. 19 No. 4, pp. 382-401.

Katie-Zillmer. (2019). 5 Reasons you should use automated logistics software. Retrieved from Medium: https://medium.com/@katie_zillmer/5-reasons-you-should-use-automatedlogistics- software-fad $3218873 \mathrm{db}$ 
International Journal of Entrepreneurship, Business and Creative Economy (IJEBCE), Vol. 2 (1), 37-47

Online Purchase Intention: A Study Among Gen X in Malaysia

Anushia Chelvarayan, Lim Fu Hao, Yeo Sook Fern, Hazlaili Hashim

Keller. (2001). Identifying the Factors Affecting Customer. Global Journal of Management and Business Research: A.

Kierczak, L. (2020). Customer Satisfaction: That's Why It's Still Important 2020. Retrieved from

Survicate: https://survicate.com/customer-satisfaction/importance-customer-satisfaction/

Kim, S., \& Pysarchik, D. (2000). Predicting purchase intentions for uni-national and bi-national products. International Journal of Retail \& Distribution Management, 28, 280-291.

Kim, D.J., D.L. Ferrin and H.R. Rao, (2008). A trust-based consumer decision-making model in electronic commerce: The role of trust, perceived risk, and their antecedents. Decision support systems, 44(2): 544-564.

Kraeuter, S., (2002). 'The role of consumers' trust in online-shopping', Journal of Business Ethics, 39(1/2 (August 1)): 43-50.

Larus, D. (2013). The Real Definition of On-Time Delivery and Three Ways to Keep Up. Retrieved from https://www.business2community.com/customer-experience/the-real-definition-ofon-time- delivery-and-three-ways-to-keep-up-0483726

Logistiko. (2020). How to avoid delivery delays. Retrieved from https://logistiko.eu/blog/how-toavoid-delivery-delays/

Malecha, V. (2018). Tips for Avoiding Online Shopping Scams \& What to Do If You're a Victim of One. Retrieved from Global Sign: https://www.globalsign.com/en/blog/tips-for-avoidingonline-shopping- scams-what-to-do-if-you-are-a-victim-of-one

McKnight, D.H., V. Choudhury and C. Kacmar, (2002). 'Developing and validating trust measures for ecommerce: an integrative typology', Information Systems Research, 13(3): 334-359.

Mummalaneni, V. and Meng, J. (2009), “An exploratory study of young Chinese customers' online shopping behaviors and service quality perceptions", Young Consumers, Vol. 10 No. 2, pp. 157169

Mutambala, S. A. (2015). Consumers' online purchase . Linnaueus University, 15-18.

Naveed, A.T. and B. Eddaoudi, (2009). Assessing the Effect of Trust and Security Factors on Consumers' Willingness for Online Shopping among the Urban Moroccans. International Journal of Business and Management Science, 2(1): 17-32

Padrón-Robaina, V. (2014). The impact of pre-sale and post-sale factors on online purchasing satisfaction: a survey. International Journal of Quality \& Reliability Management, 123-125.

Parment, A. (2013), "Generation Y vs. baby boomers: shopping behavior, buyer involvement and implications for retailing", Journal of Retailing and Consumer Services, Vol. 20 No. 2, pp. 189-199

Parry, T. (2016). Delivery Time Influences 87\% of Online Shoppers' Purchase Decisions. Retrieved from Multichannel Merchant: https://multichannelmerchant.com/must-reads/deliverytime-influences- 87-online-shoppers-purchase-decisions/

Patel, N. (n.d.). The Benefits and Importance of Customer Satisfaction. Retrieved from Neilpatel: https://neilpatel.com/blog/benefits-and-importance-of-customer-satisfaction/\#comment2631056

Peralta, E. (2015). Generation X: the small but financially powerful generation. Centro. http://www.centro.net/blog/generation-x-the-small-but-mighty-generation/

Reichheld, F. (2020). The Benefits and Importance of Customer Satisfaction. Retrieved from 
International Journal of Entrepreneurship, Business and Creative Economy (IJEBCE), Vol. 2 (1), 37-47 Online Purchase Intention: A Study Among Gen X in Malaysia

Anushia Chelvarayan, Lim Fu Hao, Yeo Sook Fern, Hazlaili Hashim

Neilpatel:

https://neilpatel.com/blog/benefits-and-importance-of-customersatisfaction/\#comment- 2631056

Sahney. (2013). A Study of Factors Influencing the Online Purchasing Intention toward Online Shopping in Thailand. digitalcommons, 280-281.

Schaupp. (2005). A Study Of E-Shopping Intention In Malaysia: The Influence Of Generation X \& Y. Australian Journal of Basic and Applied Sciences.

Schewe, C.D., Debevec, K., Madden, T.J., Diamond, W.D., Parment, A. and Murphy, A. (2013), "'If you've seen one, you've seen them all'" Are young millennials the same worldwide?", Journal of International Consumer Marketing, Vol. 25 No. 1, pp. 3-15

Staff, M. (2016). Delivery Time Top Priority for Online Shoppers. Retrieved from Material Handing \& Logistics: https://www.mhlnews.com/transportationdistribution/article/22051729/delivery-time- top-priority-for-online-shoppers 